\title{
Elevated temperature and moisture deficit stress impact on phenology, physiology and yield responses of hybrid maize
}

\section{VANAJA*, P. SATHISH, G. VIJAY KUMAR, ABDUL RAZZAQ, P. VAGHEERA, N. JYOTHI LAKSHMI, S. K. YADAV, B. SARKAR and M. MAHESWARI}

Central Research Institute for Dryland Agriculture, Santoshnagar, Hyderabad-500 059, India

*Corresponding author Email: vanajamaddi@gmail.com

\begin{abstract}
A field experiment was conducted with maize (Zea mays L.) hybrid DHM-117 under elevated temperature and moisture deficit stress to assess the phenology, physiology, biomass and yield responses. The elevated canopy temperature (ET) was maintained as $3^{\circ} \mathrm{C}$ above ambient canopy temperature (AT) in Free Air Temperature Elevation (FATE) facility and water deficit stress (WD) was imposed at initiation of tasseling stage in an open plot experiment to assess the impact of these two abiotic stresses. As compared with ambient control, the phenology of flowering with the ET was early as 3 days for anthesis, 1 day for silking and this increased 4 days for anthesis silking interval (ASI), while with WD, anthesis was delayed by 2 days, silking by 3 days and ASI increased by 3 days. It was observed that both ET and WD significantly decreased photosynthetic rate $(32 \%, 24 \%)$, stomatal conductance $(45 \%, 28 \%)$, transpiration rate $(36 \%, 44 \%)$ while increased WUE $(6 \%, 38 \%)$. It is interesting to record that there was reduction in total biomass $(11 \%, 13 \%)$ especially reproductive biomass $(44 \%, 31 \%)$ with both ET and WD while vegetative biomass was improved $(27 \%, 8 \%)$ revealing that reproductive components are effected with these abiotic stresses thereby decreased $\mathrm{HI}(42 \%, 36 \%)$. The impact of ET was more on seed set than seed filling as the reduction in test weight $(8 \%)$ was higher than at WD $(4 \%)$.
\end{abstract}

Keywords : FATE, elevated temperature, water deficit stress, photosynthetic rate, WUE, phenology, biomass.

To face the challenges of predicted global climate change especially with increasing temperatures and changing rainfall patterns many scientific investigations were initiated to quantify the impacts in order to formulate strategies for sustaining crop production. Environmental abiotic stresses such as high temperature, drought, salinity etc. severely impair plant growth and productivity. The mean annual global surface temperature is projected to increase by $1.8^{\circ} \mathrm{C}$ $5.8^{\circ} \mathrm{C}$, depending on the greenhouse emission scenario (IPCC 2007). It was estimated that cereals production in India would go down to the extent of $125 \mathrm{mt}$. and an overall increase of $2.0^{\circ} \mathrm{C}$ in temperature may cause loss in farm level net revenue by almost $8 \%$ and in GDP by around 5\% (Gahukar, 2009). Drought also being the most important environmental stress, severely impact plant growth and development, limits the plant performance and production (Shao et al., 2009).

Maize (Zea mays L.) is the third most important cereal crop after wheat and rice in terms of production globally. The optimum temperature for maize plant ranges from 22 to $32^{\circ} \mathrm{C}$ during day and 16.7 to $23.3^{\circ} \mathrm{C}$ during night. Plant growth is affected badly when the temperature decreases below $5^{\circ} \mathrm{C}$ or rises above $32^{\circ} \mathrm{C}$. High temperature stress disturbs the plant growth and yield of maize by inhibiting photosynthesis and affecting pollination due to silk desiccation and pollen abortion. When the reproductive stage of maize crop faces high temperature stress it impacts anthesis silking interval (ASI) and poor kernel setting. Leaf temperature above $38^{\circ} \mathrm{C}$ inhibits net photosynthetic rate because of thermal inactivation of enzymes. The temperatures up to $35^{\circ} \mathrm{C}$ or higher during pollination and grain filling decreases the maize yield. Degree of damage depends up on the duration and intensity of high temperature spell. Exposure to temperatures above $30^{\circ} \mathrm{C}$ damage cell division and amyloplast replication in maize kernels which reduce the size of the grain sink and ultimately yield (Commuri and Jones, 2001).

Similarly drought impacts include growth, yield, membrane integrity, pigment content, osmatic adjustment, water relations and photosynthetic activity (Praba et al., 2009). Drought triggers a wide range of physiological and biochemical processes and some of these responses will enable the plants to tolerate and adapt to such conditions with less reduction in economic yield of different crops. The 
adaptations include decreased stomatal conductance to prevent the transpirational water loss, reduced photosynthesis, accumulation of osmoprotectants like proline, FAA in the cell.

The present study was aimed to assess the phenology, physiology, biomass and yield responses of a popular maize hybrid DHM-117 under elevated crop canopy temperature condition of ambient $+3^{\circ} \mathrm{C} \pm 0.5^{\circ} \mathrm{C}$ and moisture stress condition.

\section{MATERIALS AND METHODS}

\section{Plant material and experimental design}

A field study was conducted at elevated canopy temperature and moisture stress with Hybrid maize (DHM117) during summer 2014 at Central Research Institute for Dryland Agriculture (CRIDA), located between $17.20^{\circ} \mathrm{N}$ latitude and $78.30^{\circ} \mathrm{E}$ longitude, Hyderabad, Telangana (India).The medium duration hybrid DHM-117 was with high yield potential, tolerant to lodging and responsive to nutrition.

The crop was planted with $0.30 \mathrm{~m}$ spacing within row and $0.75 \mathrm{~m}$ between rows. The recommended dose of fertilizers was applied in three splits@ $60 \mathrm{~kg} \mathrm{Nha}^{-1}$ and $60 \mathrm{~kg} \mathrm{Pha}^{-1}$ as diammonium phosphate and $30 \mathrm{~kg} \mathrm{~K} \mathrm{ha}^{-1}$ as muriate of potash as basal; $30 \mathrm{~kg} \mathrm{~N} \mathrm{ha}^{-1}$ as urea as second dose at kneehigh stage and $30 \mathrm{~kg} \mathrm{Nha}^{-1}$ as urea and $30 \mathrm{~kg} \mathrm{~K} \mathrm{ha}^{-1}$ as muriate of potash as third dose was side dressed at tasseling stage. The crop was irrigated at regular intervals and maintained pest and disease free with plant protection measures.

\section{Temperature elevation}

Free air temperature elevation (FATE) facility consisting of six rings with $8 \mathrm{~m}$ diameter at CRIDA were utilized for elevated temperature impact studies. Among the six rings, three rings were fitted with IR heating system to elevate crop canopy temperature (ET) by $3^{\circ} \mathrm{C} \pm 0.5^{\circ} \mathrm{C}$ above ambient crop canopy temperature and three rings were maintained with all structural fittings without any heating served as ambient reference (AT). Heating was provided through 24 arrays of ceramic infrared heaters of $2000 \mathrm{~W}$ capacity at $1.2 \mathrm{~m}$ above canopy to maintain elevated crop canopy temperature with height adjustment provision. This heating system delivers warming only with no photomorphogenic effects and no significant radiation emitted at wavelengths shorter than $850 \mathrm{~nm}$. The system use a proportional-integral-derivative (PID) feedback system to maintain the set temperature treatment. Data logging option and signals from each sensor are being recorded, monitored and controlled by program logic control (PLC) and supervisory control and data acquisition (SCADA) system.

\section{Water deficit stress}

Maize crop was raised under open field condition and moisture deficit stress was imposed at initiation of tasseling by withholding irrigation till wilting symptoms appeared after 8 days. The soil moisture reduced from field capacity of $16 \%$ to $6.8 \%$. The stress was released by irrigating the WD plots and maintained stress free till harvest. Soil moisture was determined by gravimetric method before providing irrigation in water deficit plots.

\section{Temperatures during crop growth}

During vegetative stage of the crop the maximum air temperature ranged from 26.1 to $35.2^{\circ} \mathrm{C}$ with an average value of $33.4^{\circ} \mathrm{C}$ while minimum temperature ranged from 21.1 to $31.6^{\circ} \mathrm{C}$ with an average value of $23^{\circ} \mathrm{C}$. While during vegetative to grain filling stage, maximum temperature ranged from 29.1 to $41.6^{\circ} \mathrm{C}$ with an average value of $37.3^{\circ} \mathrm{C}$ and minimum temperature from 23.3 to $36.2^{\circ} \mathrm{C}$ with an average value of $35.8^{\circ} \mathrm{C}$.

\section{Physiological parameters}

Net photosynthetic rate $\left(\mathrm{P}_{\mathrm{N}}\right)$, stomatal conductance (gs) and transpiration rate $(\mathrm{Tr})$ was measured with a portable photosynthesis system (LI-6400, LI-COR, Nebraska, USA) at flowering stage on fully expanded young leaf of three plants for each genotype at ET and WD stress. Photosynthetic measurements were performed between 10:00 and 12:00hrs, with irradiance was set at $1200 \mu \mathrm{mol} \mathrm{m}^{-2} \mathrm{~s}^{-1}$. Water use efficiency (WUE) was calculated as the ratio of $\mathrm{P}_{\mathrm{N}}$ and $\mathrm{Tr}$ using the formulaWUE $=\mathrm{P}_{\mathrm{N}} / \mathrm{Tr}$.

\section{Phenological observations}

The phenological observations of days to $50 \%$ tasselling, anthesis and silking were recorded when $50 \%$ of the plants had shed pollen and $50 \%$ of the plants had silks, respectively. The ASI was calculated as days to silking and days to anthesis were recorded at ET, WD and AT conditions.

\section{Biomass and yield parameters}

At maturity, three plants for each replication at each ET, WD and AT and plants were uprooted and separated in to different plant components. The roots were washed carefully to made free from adhered soil particles and used for biomass estimation. The biomass of leaves and stems was measured after drying them in hot air oven at $55^{\circ} \mathrm{C}$ till 
Table 1:Mean per se values and analysis of variance for physiological, biomass and yield parameters of maize hybrid DHM117 under control, elevated temperature (ET) and water deficit (WD) conditions

\begin{tabular}{|c|c|c|c|c|c|c|c|}
\hline Conditions & Control & ET & WD & \multicolumn{4}{|c|}{ Mean sum of square } \\
\hline \multicolumn{8}{|l|}{ Physiological parameters } \\
\hline $\mathrm{P}_{\mathrm{N}}\left[\mu \mathrm{mol} \mathrm{CO} \mathrm{m}^{-2} \mathrm{~s}^{-1}\right]$ & 45.42 & 31.06 & 34.62 & $515.52 * *$ & 0.709 & $291.816^{* *}$ & 2.966 \\
\hline $\operatorname{Tr}\left[\mathrm{mmol} \mathrm{H}_{2} \mathrm{O} \mathrm{m}^{-2} \mathrm{~s}^{-1}\right]$ & 11.49 & 7.39 & 6.34 & $42.066 * *$ & 0.043 & $66.616 * *$ & 0.223 \\
\hline WUE $\left[\mu\right.$ moles $\left.\mathrm{CO}_{2} \mu \mathrm{mol} \mathrm{H}_{2} \mathrm{O}^{-1}\right]$ & 3.95 & 4.02 & 5.47 & $0.156^{*}$ & 0.009 & $5.776 * *$ & 0.049 \\
\hline \multicolumn{8}{|l|}{ Biomass parameters per plant } \\
\hline Leaf Dry weight (g) & 45.38 & 57.54 & 38.62 & $369.66^{*}$ & 47.734 & 113.569 & 29.307 \\
\hline Vegetative biomass (g) & 137.86 & 175.18 & 147.86 & $3481.95^{*}$ & 202.771 & 249.001 & 153.091 \\
\hline \multicolumn{8}{|l|}{ Yield parametersper plant } \\
\hline Cob weight (g) & 158.62 & 89.8 & 110.25 & $11840.48 * *$ & 74.611 & $5846.724 * *$ & 58.702 \\
\hline Seed weight (g) & 123.14 & 63.7 & 69.26 & $8832.78 * *$ & 85.732 & $561.001 * *$ & 24.564 \\
\hline Seed number & 460.8 & 264 & 279.40 & $96825.60 *$ & 4629.6 & $82264.90 * *$ & 2506.400 \\
\hline Test wt (g) & 26.86 & 24.49 & 25.15 & 14.06 & 9.337 & 7.327 & 16.203 \\
\hline HI (\%) & 41.55 & 24.1 & 26.86 & $761.08 * *$ & 13.193 & $539.931 * *$ & 5.930 \\
\hline
\end{tabular}

*, ** Significant at $\mathrm{P}<0.05$ and 0.01 respectively; $\mathrm{P}_{\mathrm{N}}=$ photosynthetic rate; $\mathrm{gs}=$ stomatal conductance $\mathrm{Tr}=$ transpiration rate; WUE $=$ water use efficiency

constant weights were attained. The data on yield parameters such as cob weight, grain number, grain weight and test weight (100 grain weight) were recorded. From the recorded data sets total biomass, vegetative biomass, reproductive biomass and HI was calculated.

The analysis of variance (ANOVA) was carried out to assess the significance of treatments for the parameters studied.

\section{RESULTS AND DISCUSSION}

The response of selected maize hybrid (DHM-117) was significantly altered with ET and WD conditions for all the physiological, growth, biomass and yield parameters. The mean performance of maize hybrid at ET and WD along with ANOVA is presented in Table 1.

The ANOVA revealed that there was highly significant $(\mathrm{P}<0.01)$ difference for $\mathrm{P}_{\mathrm{N}}$ and Tr under both ET and WD. The gs varied highly significantly $(\mathrm{P}<0.01)$ with ET and significantly with WD while WUE highly significantly $(\mathrm{P}<$
0.01) with WD and significantly with ET. Enhanced temperature significantly influenced the plant height of selected maize hybrid. Total biomass and reproductive biomass varied highly significantly with both ET and WD while vegetative biomass was significant only with ET. Grain yield and HI were also recorded highly significant response with both ET and WD.

\section{Phenology}

High temperature stress significantly reduced time to $50 \%$ of flowering and total crop duration of selected hybrid maize- DHM-117. The average days to 50\% flowering i.e. tasseling, anthesis and silking of this genotype under ambient conditions was 51,54 and 56 days which was reduced to 48, 51 and 55 days respectively, when plants were grown under high temperature (Fig. 1). However anthesis silking intervals (ASI) was 2 days in ambient but it was increased to 4 days at high temperature stress. Edreira et al., (2011) reported that the proportion of plants that reached anthesis or silking was reduced under heat stress in three different maize hybrids. 


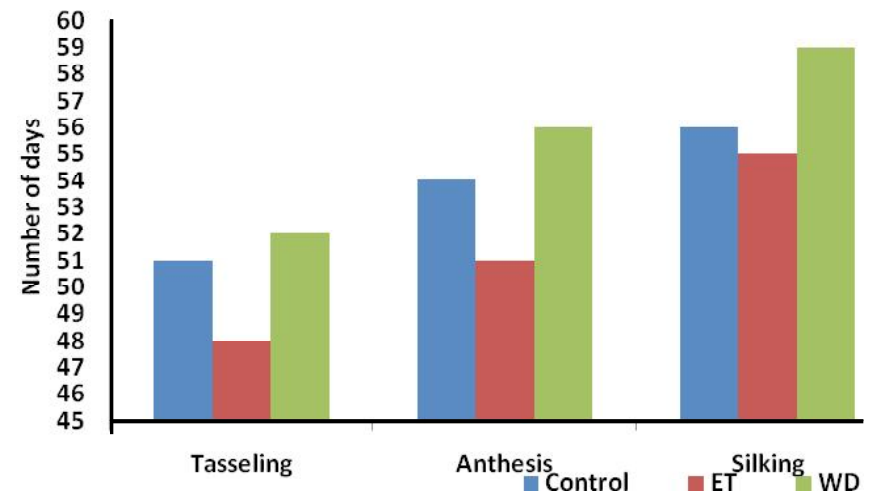

Fig.1: Days to tasseling, anthesis and silking of maize hybrid DHM-117 under control, elevated temperature (ET) and water deficit (WD) conditions

The total duration of the crop was significantly reduced with high temperature stress. The maturity of the plant was 7 days earlier with high temperature when compared with ambient control. Patel et al., (2012) also reported reduction in duration of wheat and maize due to increase in temperature.

Drought stress (WD) significantly delayed days to $50 \%$ flowering and total crop duration of hybrid maize. The average days to $50 \%$ tasseling, anthesis and silking of these genotype under control condition was 51, 54 and 56 days which was increased to 52,56 and 59 days respectively. Anthesis silking intervals (ASI) was 2 days in control condition while it was increased to 3 days with WD.

The total duration of the crop was delayed with drought stress. The maturity of the crop was delayed by 5 days with WD as compared with control. Fiedrick et al., (1989) also reported that physiological maturity affected under drought stress in maize crop.

\section{Physiological parameters}

The results revealed significant reduction in photosynthetic rate of maize hybrid in both ET (31.6\%) and WD (23.8\%) (Fig. 2). Elevated temperatures have negative effect on plant photosynthetic rate. The net photosynthetic rate $\left(\mathrm{P}_{\mathrm{N}}\right)$ of maize genotype was reduced by $32 \%$ under elevated temperature. With high temperature stress stomatal conductance (gs) was reduced by $44.4 \%$, transpiration rate (Tr) by $35.7 \%$ while WUE increased by $6.3 \%$ in maize hybrid. Dwivedi et al. (2015) observed that under elevated temperature, the mean photosynthetic rate of four rice genotypes was reduced by $21 \%$. The reduction in net photosynthetic rate in rice at high temperature was mainly attributed to the reduction of chlorophyll content as well as
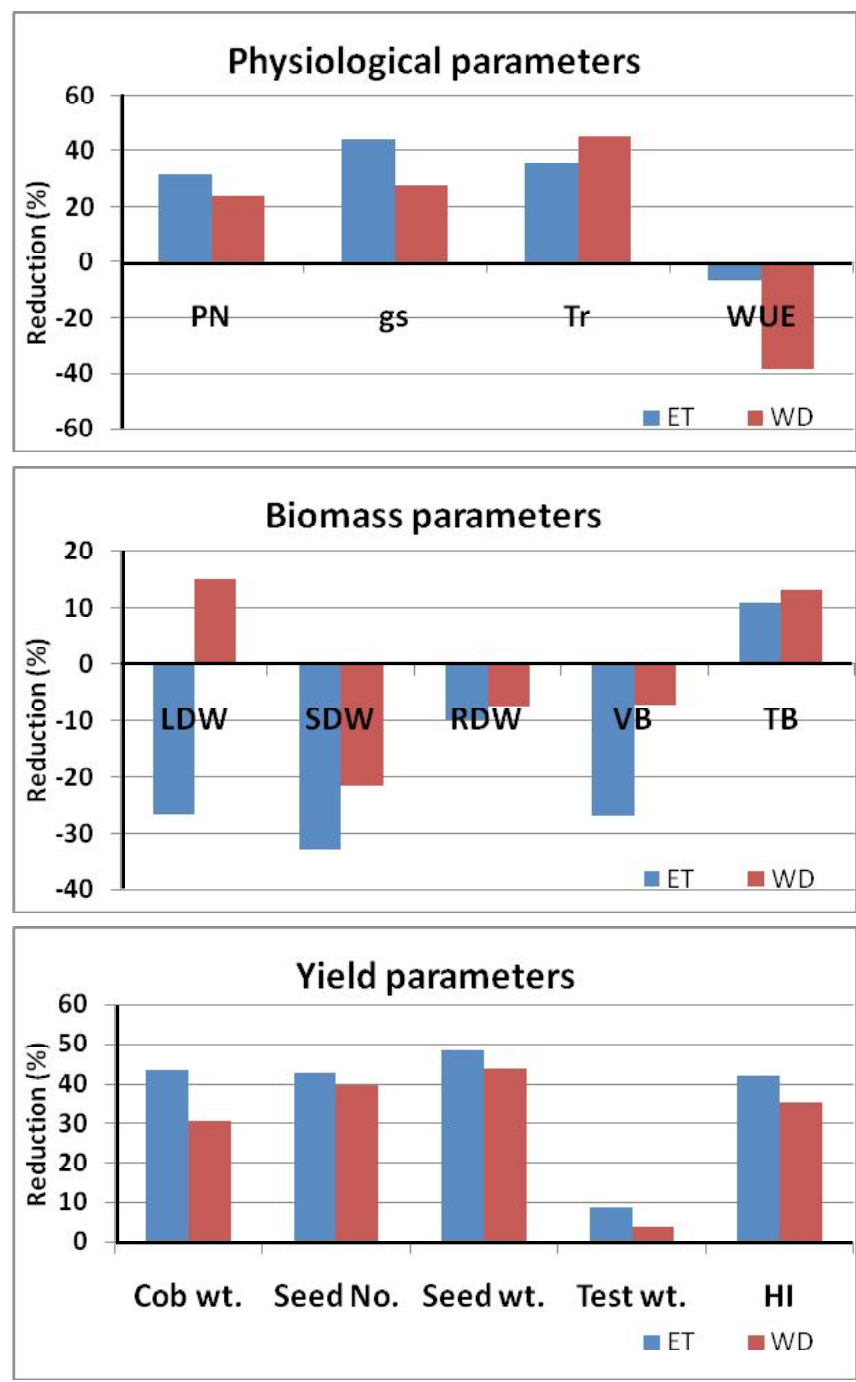

Fig. 2: The reduction (\%) of a. physiological; b. biomass and c. yield parameters of maize hybrid- DHM-117 under control, elevated temperature (ET) and water deficit (WD) conditions over control. $\mathrm{P}_{\mathrm{N}}=$ photosynthetic rate; $g s=$ stomatal conductance $; \mathrm{Tr}$ $=$ transpiration rate; $\mathrm{WUE}=$ water use efficiency; $\mathrm{LDW}=$ leaf dry weight; SDW= stem dry weight; $\mathrm{RDW}=$ root dry weight; $\mathrm{VB}=$ vegetative biomass; $\mathrm{TB}=$ total biomass; $\mathrm{HI}=$ harvest index

activities of enzymes involved in photosynthesis of flag leaves (Zhang et al., 2007).

Similarly under water deficit (WD) treatment, $\mathrm{P}_{\mathrm{N}}$ was reduced by $24 \%$, stomatal conductance by $28 \%$, transpiration rate by $44 \%$ while WUE was increased by $38 \%$. Anjum et al., (2011) indicated that drought stress in maize led to considerable decline in net photosynthesis (33\%), transpiration rate (38\%), stomatal conductance $(26 \%)$ and WUE (51\%) as compared to well-watered (WW) condition. Drought stress have a direct impact on the photosynthetic 
apparatus, essentially by disrupting all major components of photosynthesis including the thylakoid electron transport, the carbon reduction cycle and the stomatal control of the $\mathrm{CO}_{2}$ supply, together with an increased accumulation of carbohydrates, peroxidative destruction of lipid and disturbance of water balance (Allen and Ort, 2001). However, in the present investigation the reduction in Tr was higher than $\mathrm{P}_{\mathrm{N}}$ which resulted improved WUE under both ET and WD conditions.

\section{Biomass}

Both ET and WD significantly $(\mathrm{p}<0.01)$ influenced accumulation of biomass and its partitioning towards vegetative and reproductive components. Though the reduction in total biomass was $11 \%$ and $13 \%$ at $\mathrm{ET}$ and WD respectively, the vegetative biomass was increased by $27 \%$, $8 \%$ while reproductive biomass reduced by $48 \%, 44 \%$ which resulted in reduction of $\mathrm{HI}(42 \%, 35 \%)$ at $\mathrm{ET}$ and WD respectively (Fig.2). Among the vegetative biomass components, the biomass of leaf, stem and root were increased with ET. Hatfield and Prueger (2015) reported that there was no effect of high temperature stress on leaf area or vegetative biomass in maize hybrid. Kamara et al., (2003) reported that when water deficit imposed at various developmental stages of maize, it reduced biomass accumulation by $37 \%$ at silking, by $34 \%$ at grain filling period and by $21 \%$ at maturity.

\section{Yield and yield components}

Both ET and WD reduced the grain yield of selected maize hybrid, however their impact on different yield components and the magnitude of reduction varied. The reduction of yield components like cob weight $(43 \%, 30 \%)$, grain yield $(48 \%, 44 \%)$ and grain number $(43 \%, 39 \%)$ was observed respectively at ET and WD as compared with control condition (Fig.2). The impact of these stresses was more on seed set than seed filling as the reduction in test weight was only $8 \%$ and $4 \%$. Hatfield and Prueger (2015) and Patel et al., (2012) reported that grain yield in maize was significantly reduced under increased temperature condition.

\section{CONCLUSIONS}

The present investigations on responses of maize hybrid DHM-117 to two important abiotic stresses- elevated temperature by $3^{\circ} \mathrm{C}$ above ambient crop canopy temperatureas well as moisture deficit stress at initiation of tasseling revealed that both stresses significantly reduced the total biomass at harvest by significantly reducing the grain yield while improved the vegetative biomass. This clearly indicates that these stresses are not influencing the growth of the plant in general but the pattern of partitioning of biomass. The significant reduction in grain number by these stresses revealed that the pollination is affected either due to decreased pollen viability or stigma receptivity.

\section{REFERENCES}

Allen, D.J and Ort, D.R. (2001). Impact of chilling temperatures on photosynthesis in warm climate plants. Trends. Plant Sci.,6:36-42

Anjum, S.A., Wang, L.C., Farooq, M.,Hussain, M., Xue, L.Land Zou, C.M. (2011). Brassinolide application improves the drought tolerance in maize through modulation of enzymatic antioxidants and leaf gas exchange. J.Agron Crop Sci., doi:10.1111/j.1439-037X.2010.00459.X.

Commuri, P.D and Jones, R.D.(2001). Hightemperatures during endosperm cell division inmaize: a genotypic comparison under in vitro and field conditions. Crop Sci., 41: 11221130

Dwivedi, S.K., Kumar, S., Prakash, V., Mondal, S and Mishra, J.S. (2015). Influence of rising atmospheric $\mathrm{CO}_{2}$ concentrations and temperature on morphophysiological traits and yield of rice genotypes in sub humid climate of Eastern India. Am. J. Plant Sci., 6: 2339-2349

Edreira, J.I.R., Carpici, E.B., Sammarro, D and Otegui, M.E. (2011).Heat stress effects around flowering on kernel set of temperate and tropical maize hybrids.Field Crops Res., 123: 62-73

Fiedrick, J.R., Hesketh, J.D., Peters, D.B and Below, F.E.(1989). Yield and reproductive trait responses ofmaize hybrids to drought stress. Maydica, 34:319-328

Gahukar, R.T.(2009). Food Security: The Challenges ofClimate Change and Bioenergy. Curr. Sci.,96: 26-28

Hatfield, J.L and Prueger, J.H. (2015). Temperature extremes: Effect on plant growth and development. Weather and Climate Extremes, http:// dx.doi.org /10.1016/ j.wace.2015.08.001

IPCC (2007). Intergovernmental Panel on Climate Change Fourth Assessment Report: Climate Change 2007. Synthesis Report. World Meteorological Organization, Geneva

Kamara, A.Y., Menkir, A., Badu-apraku, B and lbikunle, O. 
(2003). The influence of drought stress on growth, yield and yield components of selected maize genotypes. $J$. Agric. Sci., 141:43-50

Patel, H.R., Lungaria M.M., Karande B.I., Pandey V., Yadav S.B., ShahA.V., Rao V.U.M. and Nareshkumar S. (2012). Impact of projected climate change on wheat and maize in middle Gujarat agroclimatic zone. J. Agrometeorol., Vol. 14(2): 134-137

Praba, M.L., Cairns, J.E., Babu, R.C and Lafitte, H.R. (2009). Identification of physiological traits underlying cultivar differences in drought tolerance in rice and wheat. J.Agron. Crop Sci., 195:30-46
Shao, H.B., Chu, L.Y., Jaleel, C.A., Manivannan, P., Paneerselvam, R and Shao, M.A. (2009). Understanding water deficit stress-induced changes in the basic metabolism of higher pants-biotechnologically and sustainably improving agriculture and the eco environment in arid regions of the globe. Rev.Biotechnol., 29:131-151

Zhang, G.L., Chen, L. Y., Zhang, S.T., Liu, G.H., Tang, W.B., He, Z.Zand Wang, M. (2007).Effects of hightemperature on physiological and biochemical characteristics in flag leaf of rice during heading and flowering period. Sci. Agric.Sinica., 40: 1345-1352 